\title{
The role of hyperbaric oxygen therapy (hot) as an otoprotection agent against cisplatin ototoxicity ${ }^{1}$
}

\author{
Efeito otoprotetor da oxigenoterapia hiperbárica na toxicidade causada pela cisplatina
}

\author{
Camila C. YassudaI, Ana Elisa M. RighettiI ${ }^{\mathrm{II}}$, Maria Cristina L. Cury ${ }^{\mathrm{III}}$, Miguel Ângelo Hyppolito ${ }^{\mathrm{IV}}$, José Antonio A. de \\ Oliveirav $^{\mathrm{v}}$, Omar Féres ${ }^{\mathrm{VI}}$
}

I MD, Resident in Otorhinolaryngology, Ribeirao Preto Faculty of Medicine, University of São Paulo, Brazil.

II Graduate Student of the Ribeirao Preto Faculty of Medicine, University of São Paulo, Brazil.

III PhD, Professor, Department of Ophthalmology, Otorhinolaryngology and Head and Neck Surgery, Ribeirão Preto Faculty of Medicine, University of São Paulo, Brazil.

Iv PhD, Professor, Department of Ophthalmology, Otorhinolaryngology and Head and Neck Surgery, Ribeirão Preto Faculty of Medicine, University of São Paulo, Brazil.

v Full Professor, Department of Ophthalmology, Otorhinolaryngology and Head and Neck Surgery, Ribeirão Preto Faculty of Medicine, University of São Paulo, Brazil.

VI $\mathrm{PhD}$, Professor, Division of Coloproctology, Department of Surgery and Anatomy, Ribeirão Preto Faculty of Medicine, University of São Paulo, Brazil.

\begin{abstract}
Purpose: Hyperbaric oxygen therapy (HOT) consists of intermittent inhalations of $100 \%$ oxygen at a pressure higher than $1 \mathrm{~atm}$. It is an important adjuvant therapy in pathological processes like soft tissue infections, radiation injury, gas gangrene, osteomyelitis and decompressive diseases. Cisplatin, a potent antineoplastic drug, widely used in cancer therapy is highly ototoxic causing bilateral, irreversible damage to the hearing of high frequency sounds (4-8 KHz). Objective:This experimental study conducted at the Faculty of Medicine of Ribeirao Preto, University of Sao Paulo aims to evaluate Hyperbaric Oxygen Therapy as an otoprotection agent against drug toxicity. Methods: Albino guinea pigs were divided into two groups: in Group A, 5 animals ( 10 cochlea) received cisplatin, i. p., $8.0 \mathrm{mg} / \mathrm{kg} / \mathrm{day}$ during three days and afterwards were submitted to HOT; in Group B, 3 animals (6cochlea) received cisplatin, i. p. 8.0mg/kg/day during three days. Guinea pigs were evaluated by acoustic otoemissions (AOE) and scanning electron microscopy (SEM). Results: Group B animals showed loss of auditory functions as measured by AOE and distorted outer hair cells by SEM. In Group A, outer hair cells shown by SEM images were mostly preserved. Conclusion: It is presumed that Hyperbaric Oxygen Therapy has a protector effect against cisplatin ototoxicity.
\end{abstract}

Key words: Hyperbaric Oxygen Therapy. Ototoxicity. Otoprotection. Cisplatin.

\section{RESUMO}

Introdução: A Oxigenoterapia hiperbárica (OHB) envolve a inalação de oxigênio a 100\% sob uma pressão maior que 1 atm. E um importante modo de terapia adjuvante para processos patológicos, tais como: infecção de partes moles, lesões actínicas, gangrena gasosa, osteomielite e doença descompressiva. A cisplatina e uma potente droga antineoplásica largamente utilizada para o tratamento de câncer. A ototoxicidade e um importante efeito colateral desta droga, causando dano irreversível, bilateral, na capacidade de ouvir sons de alta freqüência (4 - $8 \mathrm{KHz}$ ). Este estudo experimental, realizado na Faculdade de Medicina de Ribeirao Preto da Universidade de São Paulo nos anos de 2005 e 2006. Objetivo: Avaliar o papel da Oxigenoterapia Hiperbárica como agente otoprotector contra a toxicidade de drogas. Métodos: Cobaias albinas divididas em 2 grupos Grupo A: com 5 cobaias (10 cócleas) que receberam cisplatina 8,0 mg/kg/dia, via intraperitoneal por 3 dias, submetidas posteriormente a OHB. Grupo B: com 3 cobaias (6 cócleas) que receberam cisplatina 8,0 mg/kg/dia, via intraperitoneal por 3 dias. As cobaias foram avaliadas através de otoemissões acústicas (OEA) e por microscopia eletrônica de varredura (MEV). Resultados: Encontramos no grupo B perda da função auditiva medida pela OEA e distorção das células ciliares externas a MEV. No grupo A, a MEV as células ciliares externas foram preservadas em sua grande maioria. Conclusão: Assim podemos supor que a Oxigenoterapia Hiperbárica tem um efeito otoprotetor contra a ototoxicidade induzida pela cisplatina.

Descritores: Oxigenoterapia Hiperbárica. Ototoxicidade. Otoprotecão. Cisplatina.

1. Study performed in the Department Otorhinolaryngology, University Hospital, Ribeirão Preto Faculty of Medicine, University of São Paulo. Brazil 


\section{Introduction}

The organ of Corti is the fundamental neuro-sensorial structure in the peripheral auditive processing of the acoustic message. It consists of complex epithelial structures, with sensorial and supporting cells resting on the basilar membrane. The sensorial cells are of two types, outer and inner hair cells. Ototoxicosis are iatrogenic affections produced by therapeutic drugs on the inner ear. The drugs affect both the cochlear and / or the vestibular systems, causing transitory or permanent injury. Cisplatin, a potent antineoplastic drug, widely used in cancer therapy in adults and children shows ototoxicity as its main collateral effect, which limits therapeutic application. ${ }^{1}$

Cisplatin ototoxicity is clinically characterized by bilateral irreversible hearing detection of high frequency sounds with associated tinnitus. ${ }^{2-6}$ It is known that cisplatin ototoxicity is related to alterations in the anti-oxidant mechanisms in hair cells and several studies show that a major and dose dependent lesion is caused by cisplatin on outer cochlear hair cells, specially those at the spiral lamina responsible for transduction of high frequency sounds.

Anatomical studies of the inner ear indicate that damage may be equally produced by high cisplatin dosages or cumulative ones. The possible lesion producing mechanisms include calcium channel blockades in outer hair cells, supporting cells, stria vascularis as well as in the spiral ganglion. ${ }^{7-13}$

The last decade has seen studies aiming at a better understanding of the anti-oxidant mechanisms of outer hair cells, compromised by ototoxic drugs like aminoglycosides and cisplatin. Several potential oto protective drugs, which act blocking lesion producing mechanisms to the antioxidant system of the outer hair cells have been tested. Drugs like fosfomycin, sulfur compounds, sodium thiosulfate, diethyl carbamate, adrenocorticotropic hormone (ACTH) and derivatives, 4-methylthiobenzoic acid, lipoic acid, glutathione and esters, metionine, alpha-melanocytic stimulating hormone (melatonin) and anti-oxidants like ginkgo biloba extracts, all anti-free radicals, were effectively tested. ${ }^{11,14-20}$

Hyperbaric oxygen therapy (HOT), having an important anti-oxidant activity is being increasingly used and it is based on inhalation of $100 \%$ oxygen under pressures above $1 \mathrm{~atm}$. It is precisely indicated as a stimulant of wound healing and cellular growth.

In Brazil, the Federal Medical Council regulated HOT therapeutic use through Resolution CFM 1457/95 summarized as follows: gas embolism; decompressive disease; traumatic air embolism; gas gangrene; Fournier's syndrome; necrotic infections of soft tissues (cellulitis, fasciitis and myositis); allergic, drug or biologic toxins (Arachnida,Ophidia and Insecta) originated acute vasculitis; radiation lesions (radiation dermatitis, osteoradionecrosis and mucosal actinic lesions); acute anemia in cases where blood transfusions are not possible; acute traumatic ischemia (crushing lesions, compartment syndrome, reimplantation of amputated extremities); thermal or electric burns; refractory lesions like skin ulcers (diabetic foot, decubital scars, autoimmunee vasculitis ulcers, suture dehiscences) and compromised repairs or grafts.

Mechanical pressure effects and increased tissue oxigenation are the two active factors related to the hyperbaric environment in HOT, The physiological and pharmacological effects of high oxygen dosages are not completely known. It seems that the main effect is tissue hyperoxigenation (increased pO2) through plasma dissolved oxygen. Diffusion of the gas though skin or wounds is not significant. Increased bacterial fagocytosis by polymorphonucleates (PMN) has been observed during hyperoxygenation, as well as increased production of fibroblasts and proliferation of bone cells. ${ }^{21}$

An experimental study by Zamboni ${ }^{22}$ demonstrated that angiogenesis stimulation is directly related to the oxygen gradient in wounds.

The possible deleterious effects of excessive "free radicals" (RES, reactive oxygen species) were not verified experimentally. In contrast, anti-oxidant effects were observed though decreased neutrophil adhesion ${ }^{22}$ and NO increase, which may combine with superoxide anions blocking their effects. ${ }^{23}$ In rat experimental pancreatitis, HOT not only improved the pancreatic lesion but elevated the levels of superoxide dismutase (SOD) metabolizing the oxidative radicals. ${ }^{24}$

\section{Objective}

The study aims to evaluate the role of Hyperbaric Oxygen Therapy (HOT) as a protective agent against drug toxicity. Cisplatin, an efficient currently used ototoxic agent was selected as the experimental model drug.

\section{Methods}

Albino guinea pigs, the chosen experimental animals are easily handled, allow adequate cochlear dissection and manipulation and the i.p., intramuscular or sub-cutaneous infusion of anesthetics and experimental drugs is facilitated. The 8 adult albino guinea pigs weighing around 360-590 g and raised at the Central Animal House of the University of São Paulo- Ribeirão Preto Campus were selected through the Preyer reflex, ${ }^{25}$ kept during the experimental period at the Laboratory of Experimental Surgical Techniques, Faculty of Medicine of Ribeirão Preto, University of São Paulo, and checked every day for weight control. Animal handling and procedures were according to the guidelines of the Institute of Laboratory Animal Resources, Commission of Life Sciences, National Research Council, National Academy Press, Washington, D.C. 1996. This project was submitted and approved on the Ethics in Research Committee of FMRP-USP.

All animals were submitted to the exam of distortion product otoacoustic emissions (DPOAE) in an acoustic chamber, under anesthesia with intramuscular cetamin hydrochloride, $10 \mathrm{mg} / \mathrm{kg}$ and xylazin, $4 \mathrm{mg} / \mathrm{kg}$. The device used was the ILO 92 CAE System Otodynamics Ltd., with the frequency relation $2 \mathrm{~F} 1-\mathrm{F} 2$ and the ratio $\mathrm{F} 1 / \mathrm{F} 2=1.22$. The inclusion criterion in this study was an initial otoacoustic exam showing normal responses, which reveal outer hair cells integrity. 
Intra peritoneal administration of cisplatin (CisplatexÒ) was accompanied by hydration with $10 \mathrm{ml}$ physiological saline. The two cochlea of each guinea pig were used, since cisplatin is a systemic acting drug.

Guinea pigs were divided into two groups, A, containing 5 animals (10 cochlea) receiving $8.0 \mathrm{mg} / \mathrm{kg} / \mathrm{day}$, i.p. for three days and B, with 3 animals ( 6 cochlea) treated in the same way as A. The choice of the cisplatin dosage was based on literature reports, which show production of significant cellular lesions, with anatomical alterations verified by SEM and functional ones by otoacoustic emissions. $^{26}$

One day after final drug administration all animals were tested by otoacoustic emission, and the animals of group B euthanized in the same day. Group A guinea pigs, kept in propylene cages, were treated by Hyperbaric Oxygen Therapy, during 60 minutes at 2 ATA, on the $6^{\circ}, 8^{\circ}$ and $10^{\circ}$ day after the start of cisplatin administration and checked by otoacoustic emissions following each hyperbaric treatment.

Hyperbaric therapy was applied in a experimental chamber directly pressurized by oxygen and located at the Experimental Surgery Sector of the Department of Surgery and Anatomy, FMRP-USP.

For cochlear anatomical evaluation, guinea pigs were anesthetized by ether inhalation, decapitated and the bula containing temporal bones removed. Bula openings at the cochlear apex and round window were filled for fixation with $2.5 \%$ glutaraldehyde in $0.1 \mathrm{M}$ phosphate buffer (Sorensen) at $4^{\circ} \mathrm{C}$. The micro dissection preserved the spires and the material was kept for 12 hours in $0.1 \mathrm{M}$ buffer solution, and fixed again in $1 \%$ osmium tetroxide in phosphate buffer for one hour at $4^{\circ} \mathrm{C}$. Following dehydration by ethanol the material was dried by the critical point method with liquid $\mathrm{CO}_{2}$ in a BALTEC-CPD- "Critical Point Dryer".

Cochlea positioned on a cylindrical specimen support with a carbon conducting paste received a fine gold layer dispensed by a BALTEC SDC050 vaporizer and analyzed by SEM (JOEL JMS-5200). Representative samples of the medial third of each cochlea spiral lamina, containing 120 outer hair cells in three rows of 40 cells and 40 inner hair cells, were photographed and evaluated. In each field, hair cell counts were made at the medial third of the basal spires, second spire (E2), third spire (E3) and the cochlear basal spire, three rows of 40 cells, present or absent being counted. The cochlear apical section was not considered in this study, since normal cochlea already show a pattern of cellular disarrangement.

\section{Results}

The results in this study are based on the analysis of cochlea morphology (SEM of basal spire) and function by otoacoustic emissions (OAE). Thus, in guinea pigs of control group B the auditory function was lost in 2 of the 3 animals as measured by OAE, and outer hair cells showed distortions in the cochlea basal spire after cisplatin treatment, confirming other reports showing ototoxicity when the drug dosage was applied for the same time period (Figure1).
Animals in group A, treated by hyperbaric oxygen therapy, but previously submitted to the same dosage of cisplatin, showed outer hair cells mostly preserved (Figure 2) but distortion product otoacoustic emissions were absent in all animals.

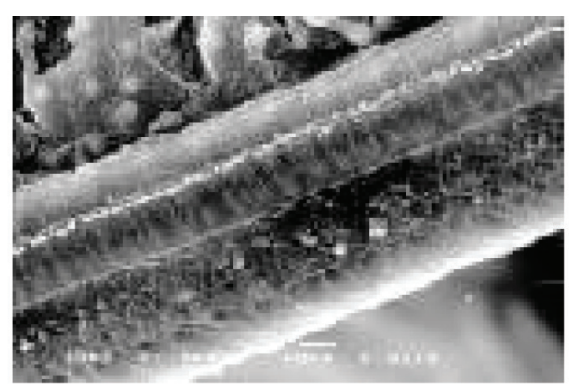

FIGURE 1- Scanning electron microscopy (SEM) image showing the lesion pattern in outer hair cells on the cochlea basal spire of guinea pigs in Group B (1000x magnification).

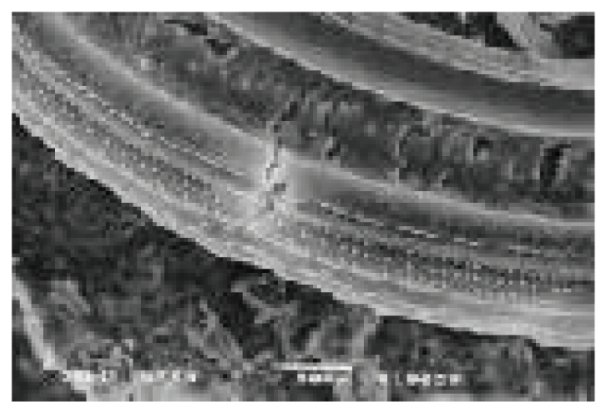

FIGURE 2- Scanning electron microscopy (SEM) image showing lesion patterns of outer hair cells in the cochlea basal spire of guinea pigs in Group A.

\section{Discussion}

Confirming observations by Cardinaal et al. ${ }^{12}$, this study showed that cisplatin induces dose-dependent cochlear alterations. High drug dosages in short periods of time $(8 \mathrm{mg} / \mathrm{kg} /$ day, three days) led to cellular lesions and significant hair damage in outer hair cells. By choosing this dosage, it was certain that lesions would be found in more than $65 \%$ of the outer cells in the basal spire as well as evident functional alterations. SEM and PDOAE evaluated the anatomical and functional alterations, respectively. PDOAE, a simple method representing the cell functional state, was employed in this study, since it is known that otoacoustic emissions evaluate the state of contraction in outer cells.

Until recently most studies about cisplatin 
ototoxicity evaluated cochlea functional alterations through action potential, somation potential and cochlear microphonics or through Brainstem Evoked Auditory Potentials (BAEP). Sokalingam et al. $(2000)^{13}$ verified that transient and distortion product registered otoemissions are a sensitive method to evaluate the functional status of outer hair cells and that the albino guinea pig is a sensitive animal. In terms of ototoxicity to cisplatin, at dosages of 8$12 \mathrm{mg} / \mathrm{kg} / \mathrm{day}$, in three days the animals show DPOAE alterations and lesioned outer hair cells, with amplitude depressions in the distortion product greater than in transient OAEs.

The literature shows several compounds being tested for protection against cisplatin ototoxicity, such as: diethylcarbamate, 4-methylthiobenzoic acid, ebselen, melatonin, lipoic acid, acetyl cysteine, phosphomycin, neurothrophins, ACTH analogs ${ }^{11,14-19}$. Several of these drugs have in vivo collateral effects and little is known about a possible interference action on the anti-neoplastic activity of cisplatin.

Analysis of the number of cochlear outer hair cells and their anatomical alterations showing hair losses and distortions indicated signs of otoprotection in Group A animals treated with Hyperbaric Oxygen Therapy. There were statistically significant differences when compared to Group B treated in the same way with cisplatin only. However, in functional studies, DPOAEs were absent reflecting a loss of hearing, which may be reversible and possible related to the presence of secretion and hemorrhagic signs during bula dissection to remove the cochlea.

The high death rate in this experimental model, 8.0 $\mathrm{mg} / \mathrm{kg} /$ day during three days is significant considering that only 3 animals in Group A survived until the end of the HOT cycles.

Concomitant use of cisplatin and Hyperbaric Oxygen Therapy is contra-indicated but in this case cisplatin was used as an efficient lesion producer in cochlea outer hair cells in a short time ${ }^{12}$ and the hyperbaric therapy only started 48 hours after the last drug dose.

Several studies on cisplatin oto and nephrotoxicity point to alterations in cell anti-oxidant potentials. It was shown that levels of glutathione (GSH) and antioxidant enzymes as superoxide dismutase (SOD), catalase, GSH peroxidase and GSH reductase are reduced in these tissues leading to lipid peroxidation, thus, to cellular toxicity. ${ }^{3,12,15,17,18}$

Anti-oxidant effects of Hyperbaric Oxygen Therapy have been observed through decrease in neutrophils adhesion $^{22}$ and increased NO production, which combine with superoxide anions blocking their effects. ${ }^{23}$ In experimental pancreatitis in rats, it was demonstrated that HOT promotes an elevation in levels of super oxide dismutase (SOD) with metabolization of oxidant radicals. ${ }^{24}$

Hyperbaric oxygen use as a therapeutic method has been progressively used and increasingly present in scientific studies. Its possible otoprotector effects should be valorized and it could become a valuable therapeutic tool. However, other effects of high pressure oxygen on the cochlea should be considered in further studies.

\section{Conclusion}

Based on the results in this study it is possible to conclude that Hyperbaric Oxygen Therapy has an otoprotector effect against cisplatin -induced ototoxicity.

\section{References}

1. Oliveira JAA, Canedo DM, Rossato M. Otoprotection of auditory hair cell against amikacin ototoxicity. Rev Bras Otorrinolaringol. 2002;68:713.

2. Stadinicki SW, Gleichman RW, Schaaeppi U. Ototoxicity of Cisdichlorommine Platinum (II) (NSC -119875): Hearing loss and Other Toxic Effects in Rhesus Monkeys. Can Chemother. 1975;59:467-80.

3. Laurell G, Engström B. Bagger- Sjöback D. Ototoxity of cisplatin. Int J Androl. 1987;10:359-62.

4. Powis GD, Hacker MP. The Toxicity of anticancer drugs. Peragamon Press, New York, 1991; p 82105 .

5. Wright CG, Schaeffer SD. Inner ear hystophatology in patiennts treated with cisplatin. Laringoscope. 1982;92:1408-13.

6. Saito T, Aran JM. Comparative ototoxicity of cisplatin during acute and chronic treatment. ORL J Otorhinolaryngol Relat Spec. 1994;56:315-20.

7. Barron SE, Daigneault EA. Effect of cisplatin on hair cell morphology and lateral wall Na,K-ATPase activity. Hear Res. 1987;26:131-7.

8. Kohn S, Fradis M, Podoshin L, Bem David Y, Zidan J, Robinson E, Nir I. Toxic effects of ciplatin alone and in combination with gentamicin in stria vascularis of guinea pigs. The Larymgoscope. 1991;101:709-16.

9. Laurell G, Engström B. The Ototoxic Effect of Ciplatin in Guinea Pigs in Relation to Dosage. Hearing Res. 1989;38:27-34.

10. Janning MH, Withworth CA, Rybak LP. Experimental model of cisplatin ototxicity in chinchilas. Otolaryngol Head Neck Surg. 1998;119:574-80.

11. Stengs CH, Klis SF, Huizing EH, Smmorenburg GF. Protective effects of a neurothophic ACTH (4-9) analog on cisplatin ototoxicity in relation to the cisplatin dose: an electrocochleogarphic study in albino guine pigs. Hear Res. 1998;124:108-17.

12. Cardinaal RM, Groot JCMJ, Huizing EH, Veldman JE, Smmorenbrg GF. Dose- depend effect of 8-day ciplatin administration upon the morphology of the albino guinea pig cochlea. Hear Res. 2000;144:135-46.

13. Sockalingam R, Freeman S, Cherny TL, Sohmer H. Effect of high- dose ciplatin on auditory brainstem responses and otoacoustic emissions in laboratory animals. Am J Otol. 2000;21:521-7.

14. Rybak LP, Radhika R, Somani SM. Mechanism of protection by diethyldithiocarbamate against cisplatin ototxicity: Antioxidant System. Fundamental and Apllied Toxicology. 1995;26:293300.

15. Rybak LP, Whitworth MA, Somani S. Application of Antioxidants and Other Agents to Prevent Ciplatin Ototoxicity. The Laryngoscope. 1999; 109:1740-4.

16. Heijmen PS, Klis SF, De Groot JC, Smoorenburg GF. Cisplatin ototoxicity and the possibly protective effect of alpha-melanocyte stimulatong hormone. Hearing Res. 1999;128:27-39.

17. Jordan JA, Schwade ND, Truelson JM. Fosfomycin 
does not inhibit the tumoricidal efficacy of cisplatinum. The Laryngoscope. 1999;109:1259-62.

18. Fukaya H, Kanno H. Experimental studies of the protective effect of ginkgo biloba extract (GBE) on cisplatin- induced toxicity in rats. Nippon Jibiinkoka Gakkai Kaiho. 1999;102:907-17.

19. Cardinaal RM, Groot JCMJ, Huizing EH, Veldman JE, Smoorenburg GF. Histological effects of Coadministration of an ACTH(4-9) analog, ORG 2766, on cisplatin ototocity in the albino guinea pig. Hear Res. 2000;144:157-67.

20. Lopez-Gonzalez MA, Guerrero JM, Rojas F, Delgado F. Ototocity caused by cisplatin is ameliorated by melatonin and other antioxidants. J Pineal Res Copenhagen. 2000;28:73-80.

21. Sheridan RL, Shank ES. Hyperbaric oxygen treatment: a brief overview of a controversial topic. J Trauma. 1999;47:426-35.

22. Zamboni WA, Roth AC, Russel RC, Graham B, Suchy H, Kucan JO. Morphologic analysis of the microcirculation during reperfusion of ischemic skeletal muscle and effect of hyperbaric oxygen. Plast Reconstr Surg. 1993;91:1110-23.

23. Buras J. Basic mechanisms of hyperbaric oxygen in the treatment of ischemia-reperfusion injury. In: HBO Symposium; South Carolina, 1999.

24. Yasar M, Yildiz S, Mas R, Dundar K, Korkmaz A. The effect of hyperbaric oxygen treatment on oxidative stress in experimental acute necrotizing pancreatitis. Physiol Res. 2003;52:111-6.

25. Jero J, Coling DE, Lawani AK. The use of Preyer's reflex in evaluation of hearing in mice. Acta Otolaryngol. 2001;121:585-9.

26. Hyppolito MA. Ototoxicidade pela cisplatina: autodefesa das células ciliadas externas e otoproteção pelo extrato de Ginkgo biloba (EGB 761) e salicilato de sódio. Tese apresentada à Faculdade de Medicina de Ribeirão Preto da Universidade de São Paulo, para a obtenção do título de Doutor em Medicina, Programa de Oftalmologia, 2004.

\author{
Correspondence: \\ Omar Féres, $\mathrm{PhD}$ \\ Department of Surgery and Anatomy \\ Ribeirão Preto Faculty of Medicine - University of São Paulo \\ 14.048-900 Ribeirão Preto, São Paulo, Brazil \\ oferes@fmrp.usp.br
}

Conflite of interest: no

Financial source: no

\section{How to cite this article:}

Yassuda CC, Righetti AEM, Cury MCL, Hyppolito MA, Oliveira JAA, Feres O. The role of hyperbaric oxygen therapy (HOT) as an otoprotection agent against cisplatin ototoxicity. Acta Cir Bras [serial on the Internet], $2008 ; 23$ Suppl 1. Available from URL: http://www.scielo.br/acb.

\section{Comments:}

Ototoxicity has been a significant problem with cisplatin, a potent antineoplastic drug. The hearing loss is usually in the high-frequency range but may occur in the lower ranges, which include the speech frequencies. Because the higher frequencies are usually involved, the hearing loss may not be symptomatic. The ototoxicity of cisplatin is dose related and is usually cumulative. The pathologic findings associated with cisplatin are selective damage to the outer hair cells of the cochlea and lesions in the organ of Corti, the spiral ganglion and cochlear nerve, and the stria vascularis. Probably an alteration in cell anti-oxidant potential might be present, leading to lipid peroxidation and cellular toxicity. Hyperbaric oxygen therapy, that consists on inhalation of 100 percent oxygen inside a hyperbaric chamber, with its anti-oxidant effect, has the potential of otoprotection against cisplatin. This was the conclusion of this well-conducted study. We must remember that hyperbaric oxygen also reverses local hypoxia, inhibits postischemic vasoconstriction, and promotes the formation of collagen matrix, which is essential for angiogenesis and restoration of blood flow to the injured tissue. However, the death rate on the experiment was high, what means that we need further studies to confirm the utility of this therapy.

\section{Wilson Salgado Filho}

MD, PhD, Department of Surgery and Anatomy, Ribeirão Preto Faculty of Medicine, University of São Paulo, Brazil. 